\section{SURFER GIRLS IN THE NEW WORLD ORDER}

By Krista Comer (Durham, NC: Duke University Press Books, 2010, 296 pp., \$23.95 paper)

REVIEWED BY DANIEL CADY, ASSOCIATE PROFESSOR, CALIFORNIA STATE UNIVERSITY, FRESNO

SIX YEARS AFTER the publication of Frederick Kohner's Gidget (1957), a twenty-one-year-old Brian Wilson begged to know whether he was loved by an admiring but diminutive "Little Surfer Girl.” From his lyrical vantage point in the water to her he mused, "I have watched you on the shore, standing by the ocean's roar." While the Beach Boys song suggests that one day the two might surf in tandem, the appropriate role assigned the landlocked girl is one of spectator cum object of desire.

In Krista Comer's thoughtful study of female surfers, hypermasculine fantasies are pushed-for the most part-to the periphery, allowing the author the needed intellectual space to cover the ever-shifting and multilayered culture of "surfer girls." What she accomplishes in that space is genuinely impressive. Employing multiple theoretical models and interdisciplinary approaches, Comer argues that surfer girls in body and action signify a cultural shift in everything-from how one might approach the historiography of the American West to "the fight against jihadist terror."

Once she contains the hypermasculine fantasies that serve to trivialize surfer girls, Comer reveals the cultural, economic, and theoretical forces that animate her subjects' world. Surfer girls exist at the nexus of multiple historical and contemporary conflicts as well as current theoretical trends. For instance, Gidget-the popular culture surfer girl prototype-must negotiate Cold War gender norms and political loyalties as well as expectations from compliant normative girls in order to remain subculturally relevant and happily autonomous. Internationally, local Mexican surfer girls navigate a world of dismissive local surfers, privileged female surf tourists, and post-NAFTA economic order. At the epicenter of surf culture (California, not Hawaii), women in the surf retail industry combat hegemonic chain stores and attempt to counter the passive images of bikini-clad surf models while continually sparring with other regional women-centered surf shops.

To mediate these international, intraregional, and-often-intergenerational conflicts, Comer advances the concept of "girl localism." She posits that female surfers initially encounter local surf breaks and steadily expand their embrace to include third-wave feminism, environmental activism, pacifism, and women-centered consumer capitalism. This allows Comer's subjects-imbued with the "spirit of Aloha”- to coalition-build across nearly any cultural divide.

Many historians will likely balk at some of Comer's assertions-particularly those regarding Cold War and western history. Granted, she makes no claim to be a historian and should not be unnecessarily burdened by idiosyncratic disciplinary standards.

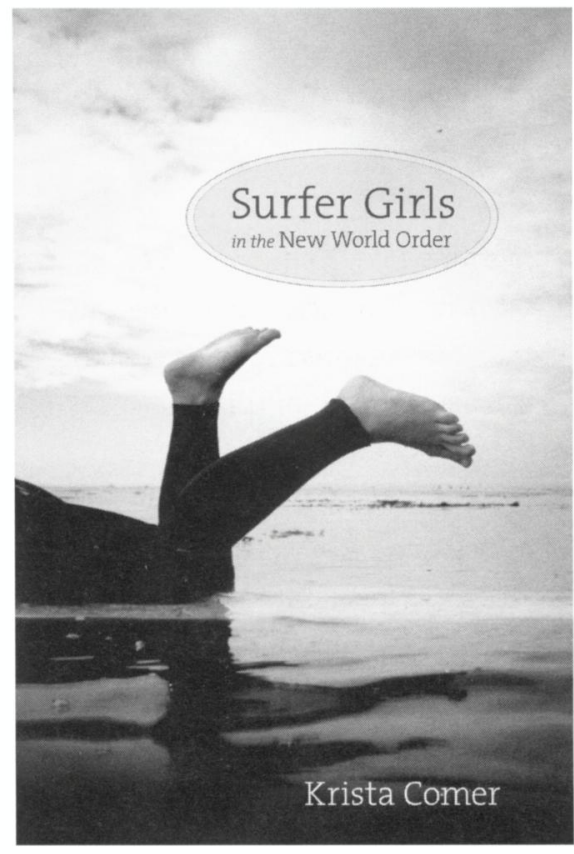

If, indeed, she were a historian, the reader would have never been privy to one of the book's best anecdotes. In the chapter on female surf vacations in Mexico, a historian would have been hard pressed to find immediate meaning in the social theater exhibited in the faux lesbian wedding held in a small local village restaurant and the ensuing "dance battle" between hip-grinding young male surfers and a group of extroverted-and equally raunchy-middle-aged Bay Area women dubbed the Hot Flashes. Comer characterizes the latter as an example of "menopausal" women "insisting on a female presence in a public space, and, hence, with female power." Ultimately, the inclusion and analyses of such happenings shed light on experiences of this particular group of young female athletes both at the forefront of an international sport and as harbingers of global transformation. Surfer Girls in the New World Order is quite simply an important book and should find its place on the bookshelves of academicians of all stripes. 